Initial Submission; Version 1

Bruce Cronin and Vladimir Popov, "Director Networks and UK Corporate Performance”, International Journal of Knowledge, Culture and Change Management, Vol 4, MC04-0126-2004.

\title{
Director Networks and UK Corporate Performance
}

Bruce Cronin and Vladimir Popov 


\section{About the Authors}

\section{Dr Bruce Cronin}

Director of Postgraduate Studies

Business School

University of Greenwich

Dr Bruce Cronin convenes the University of Greenwich's Business Network Research Group. He researches, lectures and consults on the role of business networks in strategy and innovation.

\section{Vladimir Popov}

Research Fellow

Public Services International Research Unit

University of Greenwich

Vladimir Popov, a graduate of St. Petersburg State University, the Central European University and the European University at St. Petersburg, is competing doctoral research on networks in privatised public services.

\section{Contact Details}

\section{Dr Bruce Cronin}

Director of Postgraduate Studies

Business School

University of Greenwich

Park Row

Greenwich

London SE10 9LS

United Kingdom

b.cronin@gre.ac.uk

Phone: +4420 8331 9786; Fax +4420 83319005 


\section{Director Networks and UK Corporate Performance}

\section{Main Description}

The implications of the intricate pattern of relationships formed by company directors holding positions on multiple corporate boards, or 'interlocking', have long been the subject of speculation and investigation. While this web of interfirm relationships is longer regarded as prime facia evidence of collusive activity, a growing body of research on US firms has identified a range of performance effects on firms associated with information flows in these networks. Yet research on the role of director networks and firm performance is far from comprehensive and has largely been limited to the largest US corporates.

This paper extends the existing research in this field by drawing together the principal findings to date and testing these in a different national context and with a much larger dataset than used previously. The relationship between director interlocks and corporate performance is examined among 6428 UK firms, those with annual turnover of $£ 100$ million or more. Social network analysis and regression analysis is used to detect significant relationships between the pattern of director interlinking and corporate performance.

A number of significant relationships are identified, broadly consistent with the US research but some phenomena distinctive to the UK is found, reflecting differences in the structure and sociology of capital markets in the two countries. In particular the role of executive directors is much less significant to the general financial performance of UK firms than to US firms and is more focused on reputational concerns in capital markets.

\section{Short Description}

This paper extends existing, predominantly US-based, research on the relationship between director interlinks between firms and corporate performance to a large sample of UK companies. Using an existing database, directors and financial indicators of 6428 UK companies are subjected to network analytic and regression analyses to detect significant relationships between the pattern of director interlinking and corporate performance. The distinctiveness of the UK pattern is discussed.

\section{Keywords}

Interlocking Directorates

Corporate Performance

Business Networks

Information dissemination

\section{Place as Subject}

United Kingdom 
Recent controversies regarding the governance of public companies have highlighted the importance of the selection of directors. ${ }^{1}$ Attention has focused largely on the balance between executive and non-executive directors and the establishment of mechanisms to preserve the independence and critical eye of the latter. Yet the value of directors to a company is not limited to their supervisory role. The personal experience, breadth of knowledge, business intelligence and contacts of directors are often important additions to the resource base of a firm.

While the significance of a firm marshalling such strategic knowledge assets, if they may be called, is appreciated intuitively, there has been little systematic identification of the source, impact and ultimate value of directors as a strategic resource. Business research has noted a general association between quality of directors and firm performance, although highly contingent on the mechanisms of governance alluded to above. Factors such as education, age, breadth and depth of experience, and experience relevant to the particular interests of the firm all affect the contribution of a director to the performance of a company.

Increasingly, however, research suggests that the network of relationships maintained by directors with the business community at large can have a critical impact on a firm's performance. In addition there is some evidence that directors' relationships with financial institutions can be important to the funding of firms. These findings highlight the strategic role of directors as collectors, synthesisers and applicators of business intelligence as well as an executive role as networkers.

No systematic examination of the relationship between director networking and the performance of firms has yet been undertaken, however, and the preliminary research that does exist in this area deals almost exclusively with US firms. This study takes a step towards a more systematic examination by investigating the pattern of director networking in the UK and among a much greater number of firms than in any previous directorate interlock study.

The research utilises existing databases of company directors, using social network analytical techniques to identify social relationships among directors. The pattern of relationships identified is compared to financial performance data of the respective firms with the aim of isolating the most significant types of relationship.

\section{The Effects of Director Interlocking}

The potential for the transfer of competitively valuable information between firms arises when a director of one firm serves simultaneously on the board of another firm, forming a director interlock between the firms. Because of directors' roles as part of the governing institution in a firm, they tend to have knowledge of critical information about the competitive position of the firm, particularly if they are executive directors. Interlocking directors will have knowledge of the competitive position of a range of firms in different situations and thus will tend to have greater access to competitively valuable information than directors who do not interlock. This information may concern the specific competitive position 
of another firm, 'insider' knowledge that directors are often anxious to insist is protected by professional ethics. It may reflect the greater awareness interlocking directors have of potential sources of supply of resources valuable to a firm, such as finance or new technologies. Or it may comprise a more general wisdom about the business environment and factors or strategies that contribute competitive advantage. The potential of these information channels to contribute to competitive advantage, then, suggests that corporate financial performance will be influenced by particular types of director interlocks.

The potential for interlocking directorships to provide firms with privileged information has been a central focus in the long history of studies of director interlocking. From the 1913 Pujo Commission through the elite studies of the 1960s and 70s, director interlocks were assumed prima facia evidence of potential collusion. Yet empirical evidence of collusive benefits to firms has been limited (see the survey by Mizruchi 1996), a situation reinforced by the rarity of interlocks between firms being re-established once broken (Palmer 1983), ${ }^{2}$ although around half of broken ties are reconstituted with similar types of firms (Stearns \& Mizruchi, 1986).

Studies of more general types of interlocks have also found little evidence of specific benefits. From a resource dependency perspective, where firms establish relationships with other firms to reduce uncertainty of access to critical resources, firms could be expected to maintain social relationships, such as shared directors, with suppliers of critical inputs (Pfeffer 1972). Burt (1983), however, found no effect on profitability of having important customers, suppliers or banks represented on boards. More surprisingly, perhaps, a negative relationship between performance and interlocks with banks has been found in a number of US studies, assessed in terms of solvency (Dooley 1969, ${ }^{3}$ Mizruchi \& Stearns $1988^{4}$ ) or equity-debt (Pfeffer 1972, ${ }^{5}$ Mizruchi \& Stearns 1988). ${ }^{6}$ Bank interlocking was also found to be negatively associated with profitability in the US, assessed in terms of return on assets or return on equity (Fligstein \& Brantley 1992, ${ }^{7}$ Mizruchi \& Stearns 1988), return on sales or price earnings ratio (Fligstein \& Brantley 1992). ${ }^{8}$ Such results have been interpreted as firms seeking bank representation as a response to weak profitability, and thus reducing supply uncertainty through cooption (Dooley 1969, Pfeffer 1972, Burt 1983, Mizruchi \& Stearns 1988). ${ }^{9}$ Further, Douthett and Jung (2001) found Japanese firms more responsive to poor performance the closer their directorate interlocking.

While the resource dependency perspective has only identified rather prescribed specific benefits to firms, director networks have been found to provide boards with a general 'scan' of the business environment and a channel for the diffusion of new business practices (Useem 1984, Haunschild 1994). Yet, if director interlocks provide access to business intelligence, even in general terms, some impact on firm performance should be evident, as the extent and pattern of interlocking varies between firms and between countries (see Stockman et al. 1985). Pennings (1980) and Burt (1983) found a weak positive relationship between director interlocks and profitability among US firms, while profitability has been positively associated with the proportion of outside directors (Baysinger 
\& Butler 1985, Whidbee $1997^{10}$ ). A recent study of Singaporean firms found a positive relationship between interlocking in general, profit before tax, return on sales, return on assets and solvency (Ong et al. 2003).

A number of interlock studies have focused on the assumed more activist role of executive directors and Chief Executive Officers (CEOs). Executive directors who sit on other boards are seen more likely to represent the firm they work for and thus be resource seeking or cooptive, more than providing the integrative 'scanning' role identified by Useem (1984). Booth and Deli (1996) found weaker firm performance where executives served on other boards. But Kaplan and Reishus (1990) found stronger firm performance where a CEO served on an external board. ${ }^{11}$ Yeo et al (2003) found a greater return on assets among firms with reciprocal CEO interlocks, the CEO serving on a board whose CEO served on their own board, a characteristic of large French firms.

There is reason to expect some difference in the impact of director interlocks on UK firms to that found in other countries. First, the network of director interlocks is sparse in the UK and US, the density of the largest cluster in the directorate network among the UK top 250 firms in 1976 the lowest (0.03) in Stockman and Wasseur's (1985) international comparison, although similar to the US (0.04). Similarly, Windloff (2002) recently found US and UK firms also sharing low rates of multiple interlocks with a single firm (0.6 percent and 2.1 percent, respectively cf. 14-23 percent in continental Europe). Second, UK and US firms tend to be larger and more internationalised than continental European firms. This suggests UK and US directors are more likely to be involved in broad 'scanning' than resource-specific cooptive activity, attributable to the greater reliance for funding in these countries on capital markets than on specific financial institutions (Scott 1991).

However, UK directors also differ significantly from the US in terms of interlocking propensity. Only eleven percent of UK directors held multiple directorships in 1976, the lowest in Stockman and Wasseur's (1985) survey and much lower than the USA's 18 percent. Britain also scored lowest for the number of directorships held per director, (1.15 cf. 1.28 in the US) and the number of 'big linkers' with four or more directorships (4 cf. 39 in the US) (Stockman \& Wasseur 1985). A more recent study by O’Sullivan (2000) found 0.22 external directorships per director in the UK, more frequent among longer tenured executives of larger firms, with activist boards. ${ }^{12}$ Thus, it can be expected that the 'activist' role of executive directors in interlocking for firm specific resource reasons will be much less in the UK than in the US.

A number of hypotheses can be drawn from this discussion:

H1. Larger firms have more extensive directorate interlocks as directors of larger firms are likely to have a wider range of social relations among other firms and are more likely to be sought for board positions. This hypothesis serves something of a control as this finding is well established in previous studies.

H2. Directorate interlocks will be less extensive among more internationalised firms as these firms will seek the experience of directors in countries they are operating in rather than recruiting from domestic firms. 
H3. More profitable firms will exhibit more extensive interlocking in general because the wider access to general business intelligence provided by interlocking is likely to be competitively valuable. This is in line with previous findings about US firms.

H4. More profitable firms will be closer to the centre of the network of UK directors because such firms are likely to have greater access to more competitively valuable information about the business environment. From the viewpoint of 'social capital' theory, firms with the greatest number of interlocks with firms, who themselves have many interlocks, are likely to gain the greatest information from the network. Alternatively, from the viewpoint of 'brokerage' theory it is those firms who receive the most critical information from the network who are in the position to make the greatest gains (see Burt 1992).

H5. Firms with weaker capital adequacy are likely to interlock more extensively, and interlock with financial institutions in particular, as firms in 'distress' seek to reduce uncertainty drawing on the experience of other firms. This is in line with findings about US firms.

H6. Firms with weaker capital adequacy are likely to interlock with financial institutions in particular, as they seek specialised financial expertise and perhaps preferential access to loan capital. Again, this is in line with findings about US firms, operating in a similar capital funding environment.

H7. More profitable firms are likely to exhibit more extensive executive interlocking as this is typically more purposive and likely to result in resource benefits for the firm and improved competitive advantage. But this effect will be less pervasive in the UK than among US firms because of the more limited role of executive director interlocking in the UK.

\section{Data and Analysis}

The data set for this study comprises UK registered firms in 2004 with a latest year turnover of $£ 100$ million or greater. Information on the directors and financial performance of these 6428 firms was drawn from the Bureau van Dijk FAME database (Bureau van Dijk 2004).

\section{Table 1.}

Characteristics of the main network component.

\begin{tabular}{lr} 
Characteristic & Value \\
\hline $\mathrm{N}$ & 3910 \\
Average distance & 8.041 \\
Distance-based cohesion & 0.141 \\
Distance-weighted fragmentation & 0.859 \\
Density & 0.0016 \\
$(\mathrm{SD})$ & $(0.0688)$ \\
\hline
\end{tabular}


Director interlocks and network metrics were calculated using UCINET 6 (Borgatti, Everett \& Freeman 2002). Three interlocking metrics were used: Freeman degree centrality, which counts the number of interlocks per firm, Bonacich's normalised eigenvector centrality, which measures the centrality of each firm to the network of interlocking directors as a whole, and Freeman's normalised betweenness, which is a measure of critical information throughput.

Figure 1 presents a sociogram of a subset of the interlocking directorate drawn from this analysis, the interlocks among the 1570 UK firms with turnover of $£ 500$ million or more, excluding isolated diodes for clarity. Figure 1 demonstrates the discontinuous nature of the 'network', with a large number of, generally equityrelated, small clusters around a large dense central cluster. The largest component was therefore isolated for further analysis. As Table 1 reports, and illustrated in Figure 2, this component was fragmented, with low density. ${ }^{13}$

Because of the discontinuous nature of the whole sample, eigenvector centrality and betweenness could not be meaningfully calculated as these are functions of the whole network. So these metrics were calculated only for the main component. But additional indicators of interlocking propensity - degree centrality, the interlock-director ratio, the executive director ratio, the number of executive director interlocks and the number of interlocks with financial institutions were calculated for each firm - for both the main component and the sample as a whole.

The six indicators of interlocking were then subject to ordinary least squares multiple regression against a range of financial performance variables, using SPSS 11.5. The first of these, turnover is a common measure of firm size in interlock studies (Mizruchi \& Stearns 1988). Overseas sales was included on the expectation that internationally operating firms were likely to develop distinct director networks offshore. Five measures of profitability were included: return on assets (employed by Fligstein \& Brantley 1992, Mizruchi \& Stearns 1988, Whidbee 1997' Ong et al. 2003; Yeo et al. 2003), return on shareholders' funds (employed by Fligstein \& Brantley 1992, Mizruchi \& Stearns 1988), profit margin (employed by Fligstein \& Brantley 1992, Ong et al. 1993), return on capital employed, which adds long term debt to shareholder equity, and gross profits. Three indicators of capital adequacy were included: the solvency ratio, a measure of short-term liquidity (the acid test, employed by Dooley 1969, Mizruchi \& Stearns 1988, Ong et al. 2003), gearing (the debt-equity ratio, employed by Pfeffer 1972, Allen 1974, Mizruchi \& Stearns 1988, Fligstein \& Brantley 1992), a measure of long-term debt constraint, and net tangible assets. Finally, the priceearnings ratio was included as an indicator of market assessment of corporate performance (after Fligstein \& Brantley 1992). Table 2 presents the means and standard deviations of the variables and Table 3 presents a correlation matrix of the independent variables, which does not suggest colinearity. 


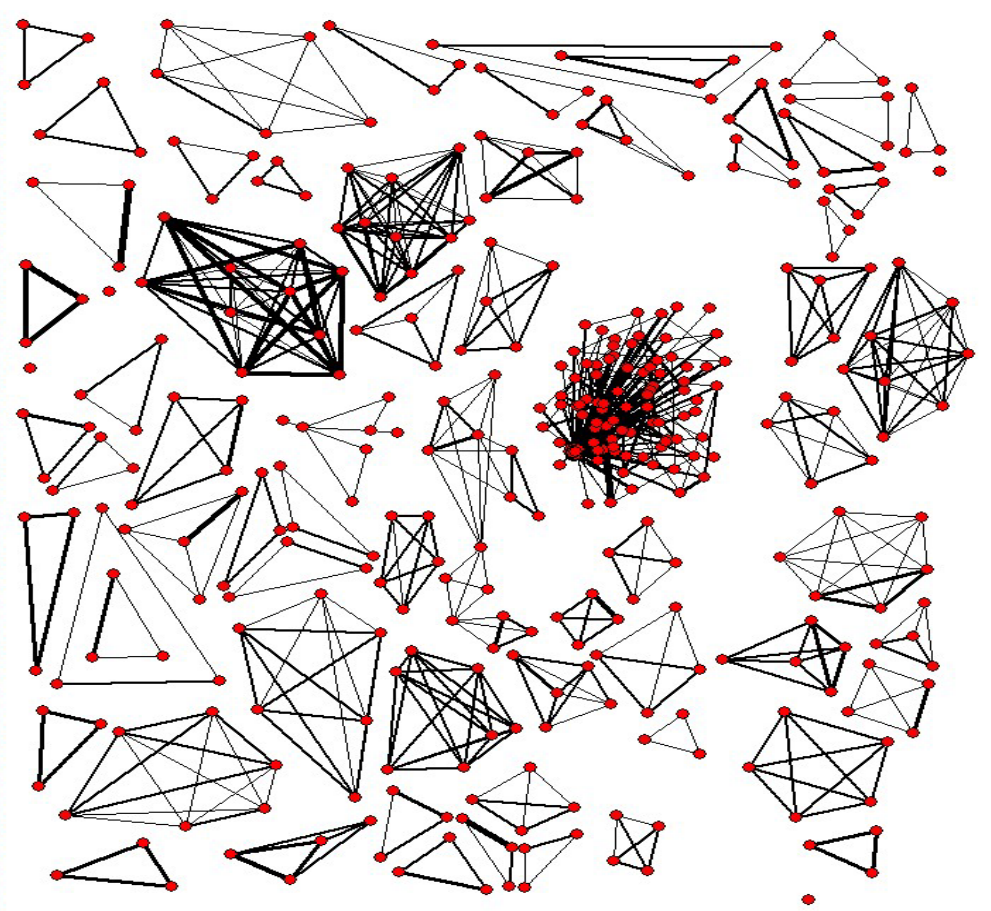

Figure 1.

Sociogram of director interlocks among subset of UK firms.

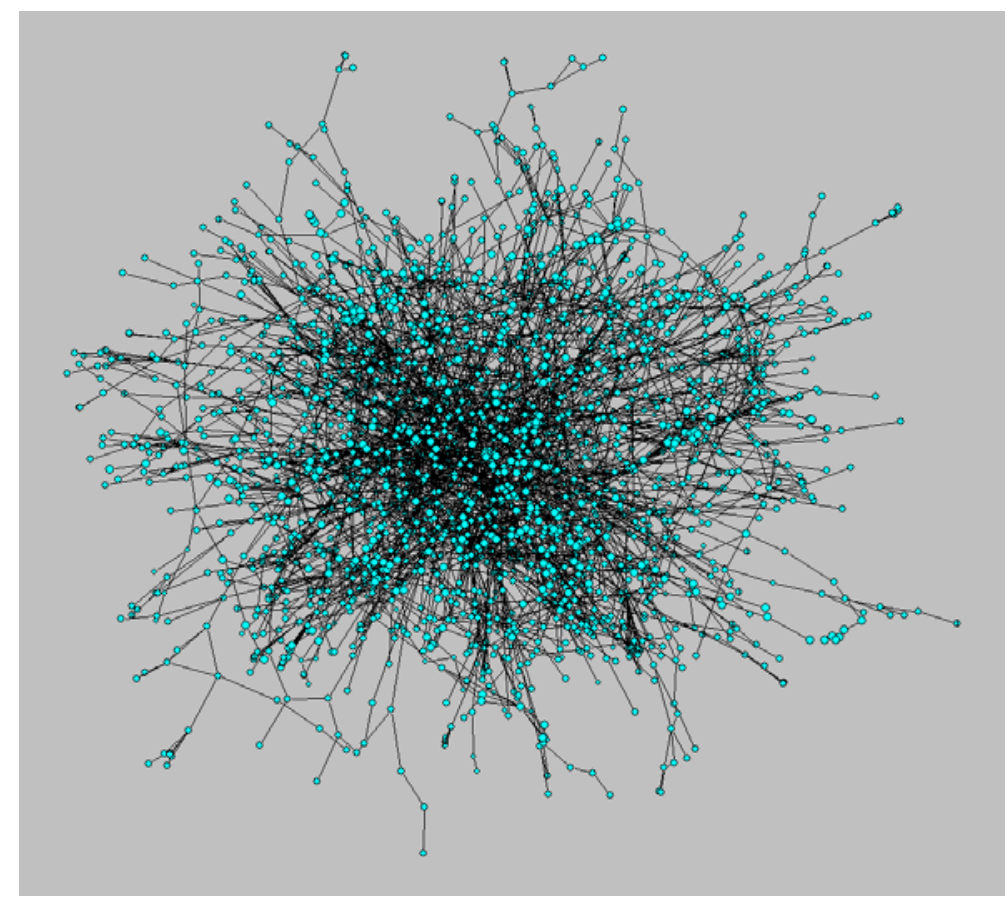

Figure 2.

Sociogram of main component of UK director interlock network. 


\section{Table 2.}

Means and standard deviations of board characteristics and variables.

\begin{tabular}{lrr}
\hline Variable & Mean & S. D. \\
\hline Directors & 6.25 & 9.9 \\
Executive directors & 1.13 & 0.47 \\
Interlocks (Freeman degree centrality) & 4.10 & 2.2 \\
Interlock propensity (interlocks per director) & 0.24 & 0.32 \\
Interlocks with financial institutions & 0.28 & 1.76 \\
Executive director proportion & 0.26 & 0.11 \\
Interlocks per executive & 1.52 & 1.91 \\
Turnover (£m latest year) & 651.9 & 2578.7 \\
Overseas turnover (£m latest year) & 166.0 & 2154.4 \\
Return on shareholders funds (\% latest year) & 22.3 & 98.0 \\
Return on capital employed (\% latest year) & 12.82 & 73.7 \\
Return on total assets (\% latest year) & 3.33 & 34.11 \\
Profit margin (\% latest year) & 4.36 & 14.33 \\
Profit before taxation (£m latest year) & 13.2 & 499.8 \\
Solvency ratio (\% latest year) & 34.5 & 34.3 \\
Gearing (\% latest year) & 438 & 1068 \\
Net tangible assets (£m latest year) & 810.8 & 4739.0 \\
Shareholders funds (£m latest year) & 504.1 & 4350.6 \\
UK turnover (£m latest year) & 459.7 & 1341.7 \\
Price / earnings ratio (low latest year) & 7.4 & 68.3 \\
\hline
\end{tabular}

\section{Table 3.}

Correlation matrix of independent variables - all firms.

\begin{tabular}{lrcrrrrrrrr}
\hline & $\mathbf{1}$ & $\mathbf{2}$ & $\mathbf{3}$ & $\mathbf{4}$ & $\mathbf{5}$ & $\mathbf{6}$ & $\mathbf{7}$ & $\mathbf{8}$ & $\mathbf{9}$ & $\mathbf{1 0}$ \\
\hline 1. Price / earnings ratio & & & & & & & & & & \\
2. Solvency ratio & 0.002 & & & & & & & & & \\
3. Profit before tax & 0.063 & -0.023 & & & & & & & & \\
4. RSF & -0.023 & 0.172 & -0.026 & & & & & & & \\
5. Gearing & 0.018 & 0.356 & 0.013 & 0.352 & & & & & & \\
6. Profit margin & -0.070 & -0.079 & -0.048 & -0.111 & -0.030 & & & & & \\
7. Return on total assets & 0.011 & -0.164 & -0.136 & 0.067 & -0.026 & -0.480 & & & & \\
8. Overseas turnover & -0.023 & -0.059 & -0.221 & 0.087 & -0.009 & -0.036 & 0.086 & & & \\
9. ROCE & 0.000 & 0.051 & 0.069 & -0.491 & -0.128 & 0.219 & -0.815 & -0.074 & & \\
10. Net tangible assets & 0.014 & 0.016 & -0.524 & -0.017 & -0.045 & -0.281 & 0.193 & 0.088 & -0.042 & \\
11. Turnover & -0.056 & 0.057 & -0.290 & -0.036 & 0.030 & 0.291 & -0.106 & -0.587 & 0.037 & -0.389 \\
\hline
\end{tabular}




\section{Results and Discussion}

Table 4 presents the results of an ordinary least squares regression for each of the dependent variables examined with respect to the sample as a whole. The first column reports the association between the number of director interlocks and the selected financial indicators. There is a significant positive association with turnover and negative association with overseas sales, supporting the first two hypotheses. There is a significant, positive association between the number of interlocks and a firm's profit margin, an interlock associated with a 0.2 percent greater profit margin. This supports the third hypothesis, although there was no significant association between interlocking and the other, arguably more important measures of profitability. There was a negative, significant association with net tangible assets, again supporting the fifth hypothesis, but with no significant results for the other measures of capital adequacy. This is in line with, but weaker than, findings in the US. Finally, there is a significant positive association between interlocking and the price/earnings ratio, which Fligstein and Brantley (1992) interpreted as a measure of profitability in the US but which must also speak about capital market perceptions. The combination of variables is significant to the pattern of director interlocking, with around 27 percent of the variation accounted for by these associations. Thus, the character of UK executive director interlocking and interlocks with financial institutions in general is notably distinct from that in the US, suggesting behavioural responses to differences in the operation of capital markets in these countries.

The second column of Table 4 reports the association between the propensity of directors to interlock and the selected financial indicators. Again, turnover is positively, and overseas turnover and net tangible assets negatively, associated with propensity to interlink, though the association is weaker than with the number of interlocks, as would be expected. This provides further support for hypotheses 1, 2 and 5. But the propensity to interlink is also significantly associated with the return on shareholders funds and negatively with the solvency ratio. This suggests that a general activism among directors, in terms of interlocks, may pay dividends in terms of profitability and in response to short-term capital adequacy issues. This adds further support to hypotheses 3 and 5 . The combination of variables is significant to the pattern of interlock propensity, accounting for around 19 percent of the variation.

The third column of Table 4 reports the association between the number of interlocks with financial institutions and the selected financial indicators. Only one variable is significant, a positive association with the solvency ratio. This is inconsistent with the sixth hypothesis, which expected similar, albeit weaker, results to research on US firms but not contrary results. While, from column 2, it can be seen that UK firms with low solvency are more likely to interlock with firms in general, the evidence here is that UK firms that interlock with financial institutions have a greater than average solvency ratio. This suggests the existence of a subset of UK firms exists with closer than average relationships with financial institutions and specific prudential benefits. 
Table 4.

Relationship between director interlocks and financial performance - all firms.

\begin{tabular}{|c|c|c|c|c|c|c|c|c|}
\hline \multirow[b]{2}{*}{$\begin{array}{l}\text { Independent } \\
\text { Variables } \\
\end{array}$} & \multicolumn{8}{|c|}{ Dependent Variables } \\
\hline & \multicolumn{2}{|c|}{ Interlocks } & \multicolumn{2}{|c|}{$\begin{array}{c}\text { Interlocks } \\
\text { per Director }\end{array}$} & $\begin{array}{c}\text { Financial } \\
\text { Interlocks }\end{array}$ & \multicolumn{2}{|c|}{$\begin{array}{c}\text { Executive } \\
\text { Director } \\
\text { Ratio } \\
\end{array}$} & $\begin{array}{l}\text { Executive } \\
\text { Interlocks }\end{array}$ \\
\hline \multirow[t]{2}{*}{ (Constant) } & 9.028 & & 1.080 & & -0.158 & 0.139 & & 1.753 \\
\hline & $(1.464)$ & & $(0.155)$ & & $(0.171)$ & $(0.008)$ & & $(0.442)$ \\
\hline \multirow{2}{*}{$\begin{array}{l}\text { Return on share- } \\
\text { holders funds (\%) }\end{array}$} & 0.044 & & 0.006 & $*$ & 0.002 & -0.000 & & 0.010 \\
\hline & $(0.024)$ & & $(0.003)$ & & $(0.003)$ & $(0.000)$ & & $(0.006)$ \\
\hline \multirow{2}{*}{$\begin{array}{l}\text { Return on capital } \\
\text { employed (\%) }\end{array}$} & -0.032 & & -0.008 & & 0.011 & -0.000 & & -0.002 \\
\hline & $(0.081)$ & & $(0.009)$ & & $(0.009)$ & $(0.000)$ & & $(0.029)$ \\
\hline \multirow{2}{*}{$\begin{array}{l}\text { Return on total } \\
\text { assets (\%) }\end{array}$} & -0.118 & & 0.002 & & -0.035 & 0.002 & & -0.011 \\
\hline & $(0.157)$ & & $(0.017)$ & & $(0.018)$ & $(0.001)$ & & $(0.055)$ \\
\hline \multirow[t]{2}{*}{ Profit margin (\%) } & 0.173 & $*$ & 0.011 & & -0.002 & -0.001 & $*$ & -0.021 \\
\hline & $(0.072)$ & & $(0.008)$ & & $(0.007)$ & $(0.000)$ & & $(0.020)$ \\
\hline \multirow{2}{*}{ 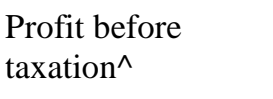 } & -0.507 & & -0.031 & & 0.019 & -0.004 & $*$ & 0.021 \\
\hline & $(0.367)$ & & $(0.039)$ & & $(0.044)$ & $(0.002)$ & & $(0.091)$ \\
\hline \multirow[t]{2}{*}{ Turnover $\wedge$} & 0.240 & $* * *$ & 0.020 & $* * *$ & -0.001 & -0.000 & & 0.011 \\
\hline & $(0.029)$ & & $(0.003)$ & & $(0.003)$ & $(0.000)$ & & $(0.011)$ \\
\hline \multirow{2}{*}{$\begin{array}{l}\text { Overseas } \\
\text { turnover^}^{\wedge}\end{array}$} & -0.174 & $* * *$ & -0.014 & $* * *$ & 0.000 & 0.001 & $* *$ & -0.021 \\
\hline & $(0.027)$ & & $(0.003)$ & & $(0.003)$ & $(0.000)$ & & $(0.012)$ \\
\hline \multirow{2}{*}{$\begin{array}{l}\text { Net tangible } \\
\text { assets^} \wedge\end{array}$} & -0.098 & $*$ & -0.011 & $*$ & -0.001 & 0.0003 & & 0.009 \\
\hline & $(0.048)$ & & $(0.005)$ & & $(0.006)$ & $(0.000)$ & & $(0.015)$ \\
\hline \multirow{2}{*}{$\begin{array}{l}\text { Solvency ratio } \\
\text { (\%) }\end{array}$} & -0.059 & & -0.008 & $*$ & $0.009 *$ & -0.000 & & -0.000 \\
\hline & $(0.033)$ & & $(0.004)$ & & $(0.004)$ & $(0.000)$ & & $(0.010)$ \\
\hline \multirow[t]{2}{*}{ Gearing (\%) } & 0.001 & & 0.0001 & & 0.0000 & -0.000 & & 0.0003 \\
\hline & $(0.001)$ & & $(0.000)$ & & $(0.000)$ & $(0.000)$ & & $(0.000)$ \\
\hline \multirow{2}{*}{$\begin{array}{l}\text { Price / earnings } \\
\text { ratio }\end{array}$} & 0.021 & $*$ & 0.001 & & -0.000 & -0.000 & & $0.006 *$ \\
\hline & $(0.010)$ & & $(0.001)$ & & $(0.001)$ & $(0.000)$ & & $(0.002)$ \\
\hline Adj. $\mathrm{R}^{2}$ & 0.271 & & 0.185 & & 0.002 & 0.045 & & 0.031 \\
\hline df & 258 & & 258 & & 279 & 277 & & 133 \\
\hline $\mathrm{F}$ & 9.732 & $* * *$ & 6.313 & $* * *$ & 1.063 & 2.173 & $*$ & 1.385 \\
\hline
\end{tabular}

Unstandardised coefficients from OLS regression reported. Standard errors in parentheses. $\wedge £ 1 / 100 ; * \mathrm{p}<.05 ; * * \mathrm{p}<.01 ; * * * \mathrm{p}<.001$. 
The fourth column of Table 4 reports the association between the ratio of executive directors to total directors and the selected financial variables, which research on US firms suggests is associated with specific benefits to firms because of executive activism. Here, there is a small significant positive association with overseas turnover and significant negative associations with profitability. While the latter supports the final hypothesis, it suggests that either executive activism is spectacularly unsuccessful in the UK or, more likely, that UK directors are motivated to expand their interlocking, perhaps in search of specific benefits or knowledge, when their firms face profitability difficulties. This contrasts with research on US firms, where financial distress is associated with financial institution interlocks. However, the combination of financial variables in this investigation accounts for only $4.5 \%$ of the variation in the propensity for executive directors to interlock.

The last column in Table 4 suggests that executive activism in the UK, in terms of director interlocks, has only limited success in terms of the financial variables investigated. While, from column 4 , the propensity of executive directors to interlock is negatively associated with profitability, the results of that interlocking are not. The only significant association with UK executive director interlocking is a positive association with the price-earnings ratio, an additional executive interlock associated with a $0.6 \%$ increase in this ratio. This is probably less an indicator of profitability than that of status effects in UK capital markets.

Some differences in this pattern emerge when the main component of the sample, the central interconnected network of interlocks, is examined. Table 5 presents the results of an ordinary least squares regression for each of the dependent variables examined with respect to the main component alone.

The first column of Table 5 reports the association between the number of director interlocks within the main component and the selected financial indicators. These are very similar to those for the sample as a whole, suggesting the dominance of the main component on the earlier results. The exception is the less significant association with the price-earnings ratio (sig. $=0.058 \mathrm{cf}$. 0.048) than that evident in the sample as a whole.

The relationship between the propensity to interlock and the financial variables, presented in column 2, also varies somewhat from the sample as a whole. The positive association with return on shareholders funds and negative association with net tangible assets found in the whole sample are not found in the main component and the negative association with solvency is weaker. The combination of variables is significant to the pattern of interlock propensity within the main component, but accounts for only seven percent of the variation. This suggests that interlocking within the central cluster of firms is less involved with issues of capital adequacy and profitability than interlocking broadly is. 
Table 5.

Relationship between director interlocks and financial performance - main component

\begin{tabular}{|c|c|c|c|c|c|c|c|}
\hline \multirow[b]{2}{*}{$\begin{array}{l}\text { Independent } \\
\text { Variables }\end{array}$} & \multicolumn{7}{|c|}{ Dependent Variables } \\
\hline & Interlocks & $\begin{array}{c}\text { Interlocks / } \\
\text { Director }\end{array}$ & $\begin{array}{c}\text { Eigen- } \\
\text { vector } \\
\text { Centrality }\end{array}$ & $\begin{array}{c}\text { Between- } \\
\text { ness }\end{array}$ & $\begin{array}{c}\text { Financial } \\
\text { Interlocks }\end{array}$ & $\begin{array}{c}\text { Executive / } \\
\text { Directors }\end{array}$ & $\begin{array}{l}\text { Executive } \\
\text { Interlocks } \\
\end{array}$ \\
\hline \multirow[t]{2}{*}{ (Constant) } & $9.53 €$ & 0.607 & 0.071 & 0.734 & -0.192 & 0.134 & 1.751 \\
\hline & (1.529) & $(0.045)$ & $(0.046)$ & $(0.167)$ & $(0.135)$ & $(0.008)$ & $(0.460)$ \\
\hline \multirow{2}{*}{$\begin{array}{l}\text { Return on share- } \\
\text { holders funds (\%) }\end{array}$} & 0.044 & 0.001 & 0.000 & 0.005 & 0.002 & 0.000 & 0.010 \\
\hline & $(0.024)$ & $(0.001)$ & $(0.001)$ & $(0.003)$ & $(0.002)$ & $(0.000)$ & $(0.006)$ \\
\hline \multirow{2}{*}{$\begin{array}{l}\text { Return on capital } \\
\text { employed (\%) }\end{array}$} & -0.032 & -0.001 & 0.001 & -0.014 & 0.007 & 0.000 & -0.003 \\
\hline & $(0.086)$ & $(0.003)$ & $(0.003)$ & $(0.009)$ & $(0.008)$ & $(0.000)$ & $(0.030)$ \\
\hline \multirow{2}{*}{$\begin{array}{l}\text { Return on total } \\
\text { assets (\%) }\end{array}$} & -0.123 & -0.002 & -0.001 & 0.009 & -0.017 & $0.002 *$ & -0.015 \\
\hline & $(0.167)$ & $(0.005)$ & $(0.005)$ & $(0.018)$ & $(0.015)$ & $(0.001)$ & $(0.059)$ \\
\hline \multirow[t]{2}{*}{ Profit margin (\%) } & $0.179 *$ & 0.003 & -0.001 & 0.011 & -0.012 & $-0.001 *$ & -0.019 \\
\hline & $(0.076)$ & $(0.002)$ & $(0.002)$ & $(0.008)$ & $(0.007)$ & $(0.000)$ & $(0.021)$ \\
\hline \multirow{2}{*}{$\begin{array}{l}\text { Profit before } \\
\text { taxation } \wedge\end{array}$} & -0.484 & -0.008 & 0.002 & $-0.118 * *$ & 0.007 & $-0.005 *$ & 0.023 \\
\hline & $(0.000)$ & $(0.000)$ & $(0.011)$ & $(0.000)$ & $(0.000)$ & $(0.000)$ & $(0.000)$ \\
\hline \multirow[t]{2}{*}{ Turnover $\wedge$} & $0.239 * * *$ & $0.0027 * *$ & 0.000 & $0.027 * * *$ & -0.002 & -0.0002 & 0.011 \\
\hline & $(0.000)$ & $(0.000)$ & $(0.001)$ & $(0.000)$ & $(0.000)$ & $(0.000)$ & $(0.000)$ \\
\hline \multirow{2}{*}{$\begin{array}{l}\text { Overseas turnover } \\
\wedge\end{array}$} & $-0.172 * * *$ & $-0.003 * *$ & 0.000 & $-0.015 * * *$ & 0.000 & $0.001 * * *$ & -0.020 \\
\hline & $(0.000)$ & $(0.000)$ & $(0.001)$ & $(0.000)$ & $(0.000)$ & $(0.000)$ & $(0.000)$ \\
\hline \multirow{2}{*}{ 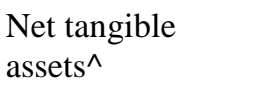 } & $-0.103 *$ & 0.000 & 0.000 & 0.000 & 0.003 & 0.000 & 0.007 \\
\hline & $(0.000)$ & $(0.000)$ & $(0.001)$ & $(0.000)$ & $(0.000)$ & $(0.000)$ & $(0.000)$ \\
\hline \multirow{2}{*}{$\begin{array}{l}\text { Solvency ratio } \\
\text { (\%) }\end{array}$} & -0.065 & $-0.002 *$ & -0.001 & -0.007 & $0.009 * *$ & 0.000 & 0.001 \\
\hline & $(0.035)$ & $(0.001)$ & $(0.001)$ & $(0.004)$ & $(0.003)$ & $(0.000)$ & $(0.011)$ \\
\hline \multirow[t]{2}{*}{ Gearing (\%) } & 0.001 & 0.000 & 0.000 & 0.000 & 0.000 & 0.000 & 0.000 \\
\hline & $(0.001)$ & $(0.000)$ & $(0.000)$ & $(0.000)$ & $(0.000)$ & $(0.000)$ & $(0.000)$ \\
\hline \multirow{2}{*}{$\begin{array}{l}\text { Price / earnings } \\
\text { ratio }\end{array}$} & 0.020 & 0.000 & 0.000 & 0.002 & -0.001 & $0.000 *$ & $0.006 *$ \\
\hline & $(0.011)$ & $(0.000)$ & $(0.000)$ & $(0.001)$ & $(0.001)$ & $(0.000)$ & $(0.002)$ \\
\hline Adj. $\mathrm{R}^{2}$ & 0.270 & 0.071 & -0.037 & 0.424 & 0.021 & 0.085 & 0.019 \\
\hline df & 242 & 242 & 242 & 242 & 242 & 240 & 124 \\
\hline $\mathrm{F}$ & $9.139 * * *$ & $2.67 * * *$ & 0.218 & $17.205 * * *$ & 1.471 & $3.018 * *$ & 1.218 \\
\hline
\end{tabular}

Unstandardised coefficients from OLS regression reported. Standard errors in parentheses. $\wedge £ 1 / 100 ;{ }^{*} \mathrm{p}<.05 ;{ }^{* *} \mathrm{p}<.01 ;{ }^{* * *} \mathrm{p}<.001$. 
The third and fourth columns report the association between a firm's centrality within the main network component and the financial variables. There is no significant association between normalised eigenvector centrality and financial performance, as would be expected from a social capital perspective, where the accumulated connections provide information advantages over other members of the network. There are, however, associations between a firm's intermediary position within the network and three financial indicators. The evidence suggests that larger firms tend to be 'between' more interlocks within the network, and more internationalised firms less-so, not at odds with the first two hypotheses. But betweenness is negatively associated with profitability, contrary to the fourth hypothesis. Firms do not seem able to gain any brokering advantage from centrality within the director interlock network and in fact there appear to be profit advantages associated with peripheral positions. The interaction among the variables accounts for 42 percent of the variation in the data.

The results presented in columns 5 and 7, for interlocks with financial institutions and by executive directors, are virtually identical to the sample as a whole. This suggests that the possible prudential and reputational benefits of networking derive from the interconnectedness of the main component rather than broad interlocking in general. As this pattern of interlocking differs markedly from the broad interlocking associated with profitability or capital inadequacy in general, this reinforces the suggestion that interlocks by executive directors and with financial institutions are the behaviour of specific subsets of firms obtaining specific benefits.

The financial performance associated with the propensity of executive directors within the main component to interlock, presented in column 6, however, does differ from that of the sample as a whole. The positive association with internationalisation and negative associations with profit and profit margin evident in the sample as a whole are present within the main component. But there are also significant positive associations with the return on total assets and the price-earnings ratio. If the propensity for executives to interlock is motivated by profitability difficulties, it appears that interlocking within the main interconnected component may be beneficial in terms of share prices and the revaluation of assets (rising return on assets alongside lower profits suggesting shrinking assets).

\section{Conclusion}

In general, the hypotheses of this study were supported by the evidence collected from this large sample and large proportion of UK firms. Director interlocking is more prevalent among larger firms and less-so among more internationalised firms. This supports the view that larger firms are able to draw from a wide circle of relationships and have a greater need to do so because of the relatively greater importance of the broad business environment to their activities. Internationalised firms most likely seek this business intelligence more in overseas markets. 
Interlocking is associated with higher profit margins and higher returns on shareholders funds. While this may represent the benefits of broad knowledge of the business environment, the business scan, there is some evidence of interlocking addressing specific resource uncertainties. In line with US findings, UK firms facing capital adequacy difficulties have a greater propensity to interlock. At the same time and somewhat as expected, executive director interlocking in the UK appears to be a response to profitability difficulties in the UK, rather than a source of profitability as reported by research in the US, and its main impact appears to be on the price-earnings ratio.

The weaker impact of financial distress on director interlocking in the UK than in the US suggests that while, after Scott (1991), UK and US capital funding share many similarities, there remain many differences. The significance of the relationship between executive activism and the price-earnings ratio may represent reputational effects in capital markets. Direct director interlocks appear to be a more important means of reducing uncertainty in the US than in the UK, where capital market participants have an arguably wider range of social relationships with which to develop and maintain relationships of confidence or trust (see Cain \& Hopkins 2001).

In these terms, the failure to find supporting evidence for our fourth hypothesis that benefits of interlocking accrue more to the most central firms, is not surprising. If director interlocks were the only or primary social relationship between firms, then the centrality of firms in UK director interlocks network would be critical to the scanning function, as it arguably is in the US. But the evidently more disparate nature of the UK director network underlies the importance of other, less formal social relationships among UK firms.

Thus, directors add value to firms in more than their direct governing role over the internal affairs of the company. The relationships directors maintain with the broader business community have significant influence on profitability. As in the US, UK firms maintain direct linkages with the boards of a range of other companies commensurate with the scale of their activities in the UK economy; broad knowledge of business affairs is valuable. For firms in financial difficulty, board level linkages have particular importance, with executive directors are centrally involved in this process. Unlike the US, such efforts seem targeted at general reputational effects in capital markets rather than at specific institutional support. Director interlocks in the UK appear to be one dimension of a rich tapestry of informal social relations that constitute the business environment.

There is scope for further research on the recognition of the value of director interlocks in the recruitment of directors and their decisions to serve on multiple boards. The identification and mapping of other dimensions of the social relationships between firms and further cross-national comparisons would deepen understanding of the reputational effects suggested here.

${ }^{1}$ We are grateful for the comments and suggestions made on this paper by Ferda Halicioglu and Leslie Johnson. 
${ }^{2}$ Useem (1984) found 25 percent of his respondents' invitations to join boards were related to inter-organisational resource issues. Richardson (1987) suggests the limited evidence of a relationship between director interlocks and profitability is due to methodological limitations, as the only important interlocks are the sort that are reconstituted. He found a strong relationship between reconstituted interlocks and profitability of Canadian firms.

${ }^{3}$ Based on the Fortune 200 nonfinancial and 50 financial corporations. The specific measure was the acid test.

${ }^{4}$ Based on a panel study of the largest and smallest Fortune 500 firm in eleven industry groups 1953-83.

${ }^{5}$ Based on 80 nonfinancial companies.

${ }^{6}$ However, the relationship varies with different indicators of 'distress' (Pennings 1980), Allen (1974) finding the equity-debt ratio positively related with bank interlocks.

${ }^{7}$ Based on a panel study of 100 US industrial firms 1969-79. Profitability measures significantly related were the price earnings ratio, return on assets, profit margin and return on equity and additionally in 1980 the debt equity ratio. The bank interlock data was limited to 63 percent of the sample, however (Fligstein \& Brantley 1992, p. 291).

${ }^{8}$ Meeusen \& Cuyvers (1985) found a positive association between financial interlocking and profitability in the Netherlands and in Belgium.

${ }^{9}$ This interpretation has generally subsumed earlier suggestions that the phenomenon reflected banks' desires to secure their loans (e.g. Aldrich 1979), though Richardson (1987) provides strong evidence of bank initiation of interlocks in Canada.

${ }^{10}$ Measured by return on assets.

${ }^{11}$ Performance measured by dividend cuts.

${ }^{12}$ Based on the 175 largest UK firms in 1995.

${ }^{13}$ Drawn in Pajek 0.85 using the Fruchterman Reingold method (Batagelj \& Mrvar, 1998). 


\section{Bibliography}

Aldrich, H. E. 1979. Organizations and Environments. Englewood Cliffs, NJ, Prentice Hall.

Allen, M. P. 1974. 'The Structure of Interorganizational Elite Cooptation: Interlocking Directorates', American Sociological Review, 39, 393-406.

Batagelj, V. and Mrvar, A. 1998. 'Pajek - Program for Large Network Analysis', Connections, 21(2), 47-57.

Baysinger, B. D. and Butler, H. D. 1985. 'Corporate governance and the board of directors: Performance effects of changes in board composition', Journal of Law, Economics and Organization, 1, 101-124.

Booth, J. and Deli, D. 1996. 'Factors Affecting the Number of Outside Directorships Held by CEOs', Journal of Financial Economics, 40, 81-104.

Borgatti, S.P., Everett, M.G. and Freeman, L.C. 2002. Ucinet for Windows: Software for Social Network Analysis. Harvard, MA, Analytic Technologies.

Bureau van Dijk 2004. FAME: Financial Analysis Made Easy. Amsterdam, Bureau van Dijk Electronic Publishing. Available: http://www.bvdep.com/FAME.html

Burt, R. S. 1983. Corporate Profits and Cooptation. New York, Academic Press. . 1992. Structural Holes: The Social Structure of Competition. Cambridge, MA, Harvard University Press.

Cain, P. J., and Hopkins, A. G. 2001. British Imperialism 1688-2000. Harlow, Pearson Education.

Dooley, P. C. 1969. 'The Interlocking Directorate', American Economic Review, 59, 314-323.

Douthett Jr., E. B. and Jung, K. 2001. 'Japanese Corporate Groupings (Keiretsu) and the Informativeness of Earnings', JIFMA - Journal of International Financial Management and Accounting, 12, 133-159.

Fligstein, N. and Brantley, P. 1992. 'Bank Control, Owner Control, or Organizational Dynamics: Who Controls The Large Modern Corporation?’, American Journal of Sociology, 98, 280-307.

Haunschild, P.R. 1994. 'How Much Is that Company Worth? Interorganizational Relationships, Uncertainty, and Acquisition Premiums', Administrative Science Quarterly, 39, 391-411.

Kaplan, S. and Reishus, D. 1990. 'Outside Directorships and Corporate Performance', Journal of Financial Economics, 27, 275-303.

Meeusen, W. and Cuyvers, L. 1985. 'The Interaction Between Interlocking Directorships and the Economic Behaviour of Companies'. In F. N Stokman, R. Ziegler and J. Scott (eds.), Networks of Corporate Power. Cambridge, Polity, pp. 45-72.

Mizruchi, M. S. 1996, 'What Do Interlocks Do? Analysis, Critique, and Assessment of Research on Interlocking Directorates', Annual Review of Sociology, 22, 271-298.

_ Directorates', Administrative Science Quarterly, 39, 194-210.

O'Sullivan, N. 2000. 'Managers as Monitors: An Analysis of the Non-executive Role of Senior Executives in UK Companies', British Journal of Management, 11, 17-29.

Ong, C.-H., D. Wan, Ong, K. -S. 2003. 'An Exploratory Study on Interlocking Directorates in Listed Firms in Singapore', Corporate Governance: An International Review, 11, 322-334.

Palmer, D. A. 1983. 'Broken Ties: Interlocking Directorates and Intercorporate Coordination’, Administrative Science Quarterly, 28, 40-55. 
Pennings, J. M. 1980. Interlocking Directorates. San Francisco, Jossey-Bass.

Pfeffer, J. 1972. 'Size and Composition of Corporate Boards of Directors', Administrative Science Quarterly, 21, 398-418.

Richardson, R. J. 1987. 'Directorship Interlocks and Corporate Profitability', Administrative Science Quarterly, 32, 367-386.

Scott, J. 1991. 'Networks of Corporate Power: A Comparative Assessment', Annual Review of Sociology, 17, 181-203.

Stearns, L. and Mizruchi, M. S. 1986. 'Broken-tie Reconstitution and the Functions of Interorganizational Networks: A Reexamination’, Administrative Science Quarterly, 31, 522-538.

Stockman, F.N. and Wasseur, F.W. 1985. 'National Networks in 1976: A Structural Comparison'. In F.N. Stockman, R. Ziegler and J. Scott (eds.), Networks of Corporate Power: A Comparative Analysis of Ten Countries. Cambridge, Polity Press, pp. 20-44.

Stockman, F. N., Ziegler R. and Scott, J. (eds). 1985. Networks of Corporate Power: A Comparative Analysis of Ten Countries. Cambridge, Polity Press.

Useem, M. 1984. The Inner Circle: Large Corporations and the Rise of Business Political Activity in the US and UK. New York, Oxford University Press.

Whidbee, D. 1997. 'Board Composition and Control of Shareholder Voting Rights in the Banking Industry', Financial Management, 30, 27-41.

Windlof, P. 2002, Corporate Networks in Europe and the United States. Oxford, Oxford University Press.

Yeo, H.-J., Pochet, C. and Alcouffe, A. 2003. 'CEO Reciprocal Interlocks in French Corporations', Journal of Management and Governance, 7, 87-108. 